\title{
REVIEW
}

\section{Effects of PPAR $\gamma$ on hypertension, atherosclerosis, and chronic kidney disease}

\author{
Akira Sugawara ${ }^{1)}$, Akira Uruno ${ }^{2)}$, Masataka $\mathrm{Kudo}^{3)}$, Ken Matsuda ${ }^{3)}$, Chul Woo Yang() and Sadayoshi Ito ${ }^{3)}$ \\ ${ }^{1)}$ Department of Advanced Biological Sciences for Regeneration, Tohoku University Graduate School of Medicine, Sendai 980 - \\ 8575, Japan \\ ${ }^{2)}$ Department of Medical Biochemistry, Tohoku University Graduate School of Medicine, Sendai 980-8575, Japan \\ ${ }^{3}$ Division of Nephrology, Endocrinology and Vascular Medicine, Tohoku University Graduate School of Medicine, Sendai $980-$ \\ 8574, Japan \\ ${ }^{4)}$ Division of Nephrology, Department of Internal Medicine, Seoul St. Mary's Hospital, The Catholic University of Korea College of \\ Medicine, Seoul 137-040, Korea
}

\begin{abstract}
Peroxisome proliferator-activated receptor (PPAR) $\gamma$ is a nuclear hormone receptor that is trans-activated by its ligands including insulin-sensitizing thiazolidinediones. PPAR $\gamma$ has recently been reported to demonstrate pleiotropic beneficial effects in the vasculatures, independent of its blood glucose-lowering effects. Firstly, PPAR $\gamma$ ligands have been shown to lower blood pressure in both animals and human. The effect may possibly be mediated via the PPAR $\gamma$-mediated inhibition of the angiotensin (Ang) II type 1 receptor expression as well as Ang II-mediated signaling pathways, which may result in the suppression of the renin-angiotensin system (RAS). Secondly, the progression of atherosclerosis was also prevented by PPAR $\gamma$ ligands in both animals and human. In addition to the PPAR $\gamma$-mediated suppression of the RAS and the thromboxane $\mathrm{A}_{2}$ system, protective effects of PPAR $\gamma$ ligands on endothelial function may also be involved. Thirdly, reno-protective effects of PPAR $\gamma$ ligands, especially on reducing urinary albumin, have been observed in both animals and human not only in diabetic nephropathy but also in non-diabetic renal diseases. The reno-protective effects may be mediated, at least in part, via the PPAR $\gamma$ ligand-induced blood pressure-lowering effects, protective effects on endothelial function, and vasodilating effects on the glomerular efferent arterioles. Additionally, anti-cancer effects of PPAR $\gamma$ ligands have recently been reported. Taken together, usefulness and effectiveness of PPAR $\gamma$ ligands on lifestyle related diseases will be increasingly appreciated.
\end{abstract}

Key words: Thiazolidinediones, Angiotensin II, Thromboxane, Endothelium, Kidney

PEROXISOME PROLIFERATOR-ACTIVATED RECEPTOR (PPAR) $\gamma$ is a nuclear hormone receptor that binds to the PPAR response element (PPRE), a direct repeat of AGGTCA spaced by a nucleotide, on DNA as a heterodimer with retinoid $\mathrm{X}$ receptor (RXR), and is trans-activated by its ligands including 15 -deoxy- $\Delta^{12,14}$-prostaglandin $\mathrm{J}_{2}\left(15 \mathrm{dPGJ}_{2}\right)$ and insulin-sensitizing thiazolidinediones (TZDs) [1] (Fig. 1). Recently, PPAR $\gamma$ has been reported to demonstrate pleiotropic vascular effects, independent of its blood glucose-lowering effect, that are protective against the progression of hypertension and atherosclerosis [2].

Received Sep. 22, 2010; Accepted Sep. 24, 2010 as K10E-281 Released online in J-STAGE as advance publication Sep.28, 2010 Correspondence to: Akira Sugawara, M.D., Ph.D., Department of Advanced Biological Sciences for Regeneration, Tohoku University Graduate School of Medicine, 2-1, Seiryo-machi, Aobaku, Sendai, 980-8575, Japan. E-mail: akiras2i@med.tohoku.ac.jp.
In the present review, we will describe about the recent findings, including our data, regarding the beneficial aspects of PPAR $\gamma$ in the vasculatures.

\section{Effects of PPAR $\gamma$ on Hypertension}

Several clinical studies have demonstrated the blood pressure-lowering effect of PPAR $\gamma$ ligand TZDs [3]. Recently, PROactive (PROspective pioglitAzone Clinical Trial In macroVascular Events) study, which included 5,238 enrolled type 2 diabetic patients, have also demonstrated a significant decrease of systolic blood pressure ( $3 \mathrm{mmHg}$ ) by TZD (pioglitazone) treatment [4]. Since the renin-angiotensin system (RAS) plays the most important roles in the progression of hypertension, we examined the effect of PPAR $\gamma$ ligands on angiotensin (Ang) II type 1 receptor (AT1R) expression in vascular smooth muscle cells 


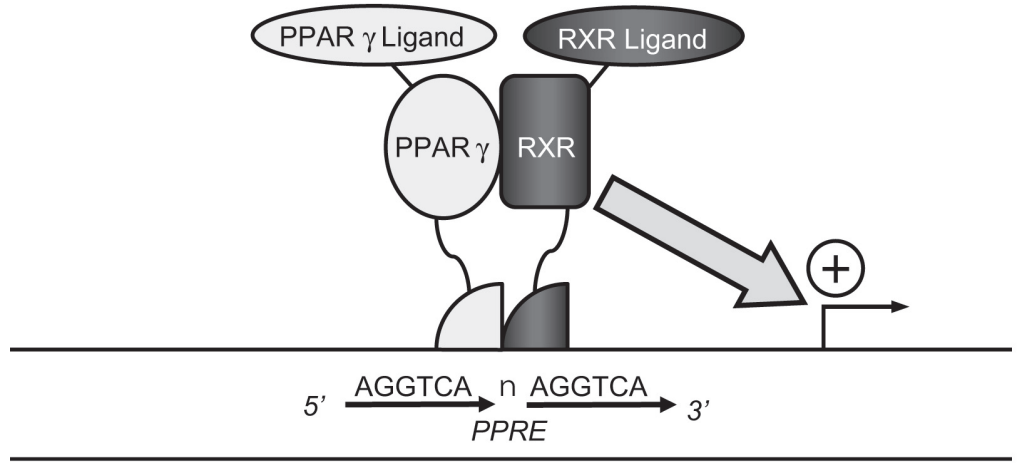

Fig. 1 Schematic representation of PPAR $\gamma /$ RXR heterodomer binding to PPRE on DNA.

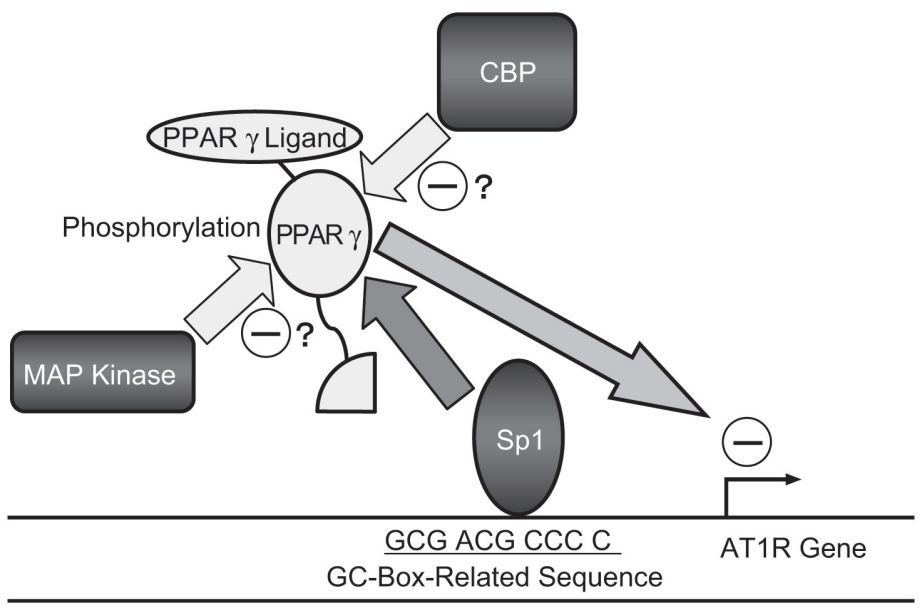

Fig. 2 Possible mechanisms of PPAR $\gamma$-mediated transcription suppression of the AT1R gene promoter. Ligand-activated PPAR $\gamma$ may inhibit Sp1 binding to the GC-box-related sequence due to a protein-protein interaction, which may result in the transcription suppression. Co-activator $\mathrm{CBP}$ and PPAR $\gamma$ phosphorylation by MAP kinase may modulate the function of PPAR $\gamma$.

(VSMCs). Interestingly, $15 \mathrm{dPGJ}_{2}$ as well as TZDs (pioglitazone, troglitazone, and rosiglitazone) dosedependently decreased the expression of AT1R mRNA $[5,6]$. Transcriptional analyses using rat AT1R gene promoter $(-1969 /+104)$ and an examination of AT1R mRNA stability using actinomycin D revealed that PPAR $\gamma$ ligands decreased AT1R expression at the gene transcription level, and mutation analyses of the promoter demonstrated that the transcription suppression was mediated via the -58/-34 region (TGC AGA GCA GCG ACG CCC CCT AGG C) of the AT1R gene promoter which contained a GC-box-related sequence (underlined) but no PPREs [5] (Fig. 2). The sequence was demonstrated to be bound to and trans-activated by Sp1 [5]. Transcriptional analyses with over-expres- sion of PPAR $\gamma$ and Sp1, electrophoretic mobility shift assays, and glutathione S-transferase pull-down assays revealed that ligand-activated PPAR $\gamma$, which could not bind to the GC-box-related sequence, could bind to Sp1 via a protein-protein interaction [5]. Additionally, Sp1 binding to the sequence was inhibited by PPAR $\gamma$ co-incubation [5]. It is therefore speculated that the PPAR $\gamma$-induced AT1R gene transcription suppression was mediated via the inhibition of Sp1 binding to DNA due to the protein-protein interaction between ligand-activated PPAR $\gamma$ and Sp1 (Fig. 2). Interestingly the transcription suppression was abrogated by co-activator CERB-binding protein (CBP) over-expression and PPAR $\gamma$ phosphorylation by mitogen-activated protein (MAP) kinase [7], most likely due to the function- 


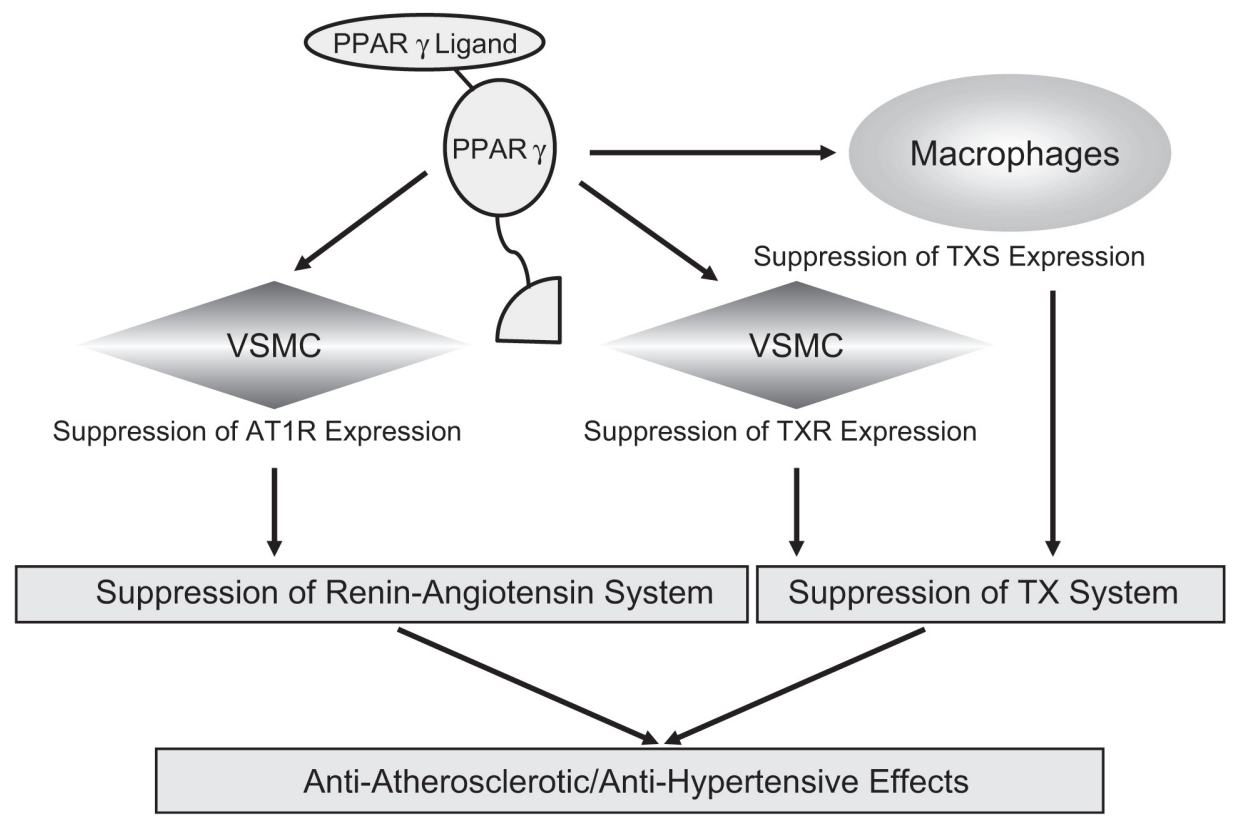

Fig. 3 Speculated effects of PPAR $\gamma$ against atherosclerosis and hypertension via the suppression of the RAS and the TX system.

al modification of PPAR $\gamma$ (Fig. 2). The PPAR $\gamma$ ligandmediated suppression of AT1R expression was also demonstrated in Ang II-infused rats [8, 9]. Moreover, PPAR $\gamma$ ligands have been shown to suppress Ang IIinduced phosphatidylinositol 3-kinase and MAP kinase [9], and ameliorate Ang II-mediated inflammatory responses by interfering with the Toll-like receptor 4-dependent signaling pathway [10]. Therefore, PPAR $\gamma$ not only down-regulates AT1R expression, but also inhibits Ang II-mediated signaling pathways, which may result in the suppression of the RAS (Fig. 3). Blood pressure-lowering effects of PPAR $\gamma$ ligands have previously been demonstrated in the Ang II-infused SpragueDawley rats $[8,9]$, spontaneously hypertensive rats [11], deoxycorticosterone acetate-salt rats [12], and hypertensive transgenic mice expressing both human renin and human angiotensinogen transgenes [13]. On the other hand, transgenic mice expressing a dominant negative PPAR $\gamma$ P465L mutation demonstrated hypertension [14], which was consistent to the phenotype of patients who had an equivalent PPAR $\gamma$ P467L mutation [15], without affecting components of the RAS. Taken together, ligand-activated PPAR $\gamma$ may lower blood pressure through several different mechanisms, in addition to the inhibition of the RAS.

\section{Effects of PPAR $\gamma$ on Atherosclerosis}

Thromboxane (TX) $\mathrm{A}_{2}$ exerts contraction and proliferation of VSMCs, which possibly leads to the progression of atherosclerosis. In order to examine if the TX system was affected by PPAR $\gamma$, we studied the effects of PPAR $\gamma$ ligands on the expression of TX synthase (TXS) in macrophages [16] and TX receptor (TXR) in VSMCs $[6,17]$. Interestingly, PPAR $\gamma$ was observed to suppress both TXS and TXR at the gene transcription level $[6,16,17]$. Detailed analyses revealed that ligand-activated PPAR $\gamma$ inhibited NRF2 (nuclear factor E2-related factor 2) binding to DNA in TXS gene [16], and Sp1 binding to DNA in TXR gene [17], both via protein-protein interactions. Taken together, PPAR $\gamma$ most likely suppress the progression of atherosclerosis through the inhibition of the TX system including both synthesis and action/signal transduction of TXA $_{2}$ (Fig. 3), in addition to the inhibition of the RAS.

Although atherosclerosis usually proceeded from endothelial dysfunction, PPAR $\gamma$ ligands have been reported to improve endothelial function not only in streptozotocin-induced diabetic rats [18], diabetic $\mathrm{db} /$ $\mathrm{db}$ mice [19], but also in type 2 diabetic patients [20] and non-diabetic patients with coronary artery disease [21]. Additionally, transgenic mice that specifically 
expressed dominant-negative PPAR $\gamma$ in endothelium demonstrated the development of endothelial dysfunction in response to a high-fat diet [22]. PPAR $\gamma$ ligands have also been reported to reduce intimal and medial complex thickening in carotid arteries and in-stent restenosis after coronary intervention in both diabetic and non-diabetic patients [23] as well as neointima formation after balloon injury in rats [24] and in-stent restenosis in atherosclerotic rabbits [25]. In order to examine the direct effects of PPAR $\gamma$ ligands on endothelial gene expression, we performed DNA microarray analyses. Confluent human umbilical vein endothelial cells (HUVEC) were treated with pioglitazone $(100 \mathrm{nM})$, concentration of which was similar to serum concentration of patients after its single oral administration, for 24 hours. Their RNAs were thereafter extracted, and were processed for DNA microarray analyses using Human Genome Oligo Set (Operon Biotechnologies Inc.) representing approximately 35,000 genes. Representative regulated genes are shown in Table 1. Pioglitazone induced expression of tissue inhibitor of metalloproteinases-3, prostacyclin receptor, kallikrein 6 and 11, prostaglandin E2 receptor (EP1 subtype), and microsomal glutathione S-transferase 3, and suppressed expression of matrix metalloproteinase-10 and plasminogen activator inhibitor-2 [26]. PPAR $\gamma$ ligands may therefore be beneficial for the protection of endothelial function in terms of gene expression regulation. Recently, PPAR $\gamma$ ligands have also been reported to stimulate endothelial nitric oxide production in HUVEC [27], and increase number and function of endothelial progenitor cells in patients with coronary artery disease [28]. These observations, in addition to our DNA microarray findings, may contribute to the anti-atherogenic effects of PPAR $\gamma$ ligands.

\section{Protective Effects of PPAR $\gamma$ in the Kidney}

In order to examine intra-renal localization of PPAR $\gamma$ protein, we generated isoform-specific antiPPAR $\gamma$ antibody and performed immunohistochemical analyses of Sprague-Dawley rat kidneys using the antibody $[29,30]$. PPAR $\gamma$ protein was observed to be widely expressed in the nuclei of mesangial and epithelial cells in glomeruli, proximal and distal tubules, the loop of Henle, medullary collecting ducts [29]. Interestingly, PPAR $\gamma$ protein expression was also observed in intima/media of renal vasculatures [29]. We
Table 1 Effects of pioglitazone on endothelial gene expression

\begin{aligned} & \hline Genes up-regulated by pioglitazone treatment \\ & \hline Tissue inhibitor of metalloproteinases-3 3.0 -fold \\ & Prostacyclin receptor 5.8 -fold \\ & Kallikrein 6 2.6 -fold \\ & Kallikrein 11 5.6 -fold \\ & Prostaglandin E2 receptor, EP1 subtype 3.7 -fold \\ & Microsomal glutathione S-transferase 3 2.1 -fold \\ & \hline Genes down-regulated by pioglitazone treatment \\ & \hline Matrix metalloproteinase-10 0.45 -fold \\ & Plasminogen activator inhibitor-2 0.49 -fold \\ & \hline\end{aligned}

previously reported the vasodilating effects of TZD troglitazone on the glomerular efferent arterioles in the microdissected rabbit kidneys [31]. Considering the immunohistochemical data, the vasodilating effects may possibly be mediated via PPAR $\gamma$ expressed in the intra-renal arterioles. We also observed the induction of PPAR $\gamma$ protein expression in distal tubules and cortical collecting ducts by TZD rosiglitazone administration to Sprague-Dawley rats [30]. These findings are potentially interesting in terms of pathophysiology, since TZDs have been reported to expand body fluid volume through PPAR $\gamma$ stimulation of the epithelial $\mathrm{Na}^{+}$channel-mediated renal salt absorption [32].

Reno-protective effects of PPAR $\gamma$ ligands on type 2 diabetic patients with nephropathy, especially their effects on reducing urinary albumin, have recently been reported [33]. Additionally, similar effects have been observed in animal experiments using various rodent models of type 2 diabetes [33]. The mechanisms by which PPAR $\gamma$ ligands reduce urinary albumin remain unclear. In addition to their vasodilating effects on the glomerular efferent arterioles [31], their above described effects regarding lowering blood pressure as well as protecting endothelial function may possibly be involved. Additionally, reno-protective effects of PPAR $\gamma$ ligands in non-diabetic renal diseases have recently been reported [34], indicating the general usefulness of PPAR $\gamma$ ligands on chronic kidney disease. We have also demonstrated reno-protective effects of TZD rosiglitazone against cyclosporine-induced renal injury in Sprague-Dawley rats [35].

\section{Conclusion}

More than a decade had passed since the pleiotropic effects of PPAR $\gamma$ was first reported. However, numer- 
ous reports regarding novel effects of PPAR $\gamma$ are still publishing every month. In addition to the above described effects against blood pressure, atherosclerosis, and kidney dysfunction, anti-cancer effects of PPAR $\gamma$ ligands have recently been reported [36]. We have also reported the inhibitory effects of PPAR $\gamma$ ligand TZDs on the cell growth of gastrointestinal cancer cell lines [37]. Therefore, usefulness and effectiveness of
PPAR $\gamma$ ligands on lifestyle related diseases will be increasingly appreciated.

\section{Acknowledgement}

We would like to thank Professor I. Kojima (Gunma Univ.) for giving us the opportunity to write this review article.

\section{References}

1. Kliewer SA, Xu HE, Lambert MH, Willson TM (2001) Peroxisome proliferator-activated receptors: from genes to physiology. Recent Prog Horm Res 56: 239263.

2. Marchesi C, Schiffrin EL (2008) Peroxisome proliferator-activated receptors and the vascular system: beyond their metabolic effects. J Am Soc Hypertens 2: $227-$ 238.

3. Sarafidis PA, Lasaridis AN (2006) Actions of peroxisome proliferator-activated receptors-gamma agonists explaining a possible blood pressure-lowering effect. Am J Hypertens 19: 646-653.

4. Dormandy JA, Charbonnel B, Eckland DJ, Erdmann E, Massi-Benedetti M, Moules IK, Skene AM, Tan MH, Lefèbvre PJ, Murray GD, Standl E, Wilcox RG, Wilhelmsen L, Betteridge J, Birkeland K, Golay A, Heine RJ, Korányi L, Laakso M, Mokán M, Norkus A, Pirags V, Podar T, Scheen A, Scherbaum W, Schernthaner G, Schmitz O, Skrha J, Smith U, Taton J (2005) Secondary prevention of macrovascular events in patients with type 2 diabetes in the PROactive Study (PROspective pioglitAzone Clinical Trial In macroVascular Events): a randomised controlled trial. Lancet 366: 1279-1289.

5. Sugawara A, Takeuchi K, Uruno A, Ikeda Y, Arima S, Kudo M, Sato K, Taniyama Y, Ito S (2001) Transcriptional suppression of type 1 angiotensin II receptor gene expression by peroxisome proliferator-activated receptor-gamma in vascular smooth muscle cells. Endocrinology 142: 3125-3134.

6. Sugawara A, Takeuchi K, Uruno A, Ikeda Y, Arima S, Sato K, Kudo M, Taniyama Y, Ito S (2001) Differential effects among thiazolidinediones on the transcription of thromboxane receptor and angiotensin II type 1 receptor genes. Hypertens Res 24: 229-233.

7. Sugawara A, Takeuchi K, Uruno A, Kudo M, Sato K, Ito S (2003) Effects of mitogen-activated protein kinase pathway and co-activator CREB-binding protein on peroxisome proliferator-activated receptor-gammamediated transcription suppression of angiotensin II type 1 receptor gene. Hypertens Res 26: 623-628.
8. Diep QN, El Mabrouk M, Cohn JS, Endemann D, Amiri F, Virdis A, Neves MF, Schiffrin EL (2002) Structure, endothelial function, cell growth, and inflammation in blood vessels of angiotensin II-infused rats: role of peroxisome proliferator-activated receptorgamma. Circulation 105: 2296-2302.

9. Benkirane K, Viel EC, Amiri F, Schiffrin EL (2006) Peroxisome proliferator-activated receptor gamma regulates angiotensin II-stimulated phosphatidylinositol 3-kinase and mitogen-activated protein kinase in blood vessels in vivo. Hypertension 47: 102-108.

10. Ji Y, Liu J, Wang Z, Liu N, Gou W (2009) PPARgamma agonist, rosiglitazone, regulates angiotensin II-induced vascular inflammation through the TLR4-dependent signaling pathway. Lab Invest 89: 887-902.

11. Wu L, Wang R, De Champlain J, Wilson TW (2004) Beneficial and deleterious effects of rosiglitazone on hypertension development in spontaneously hypertensive rats. Am J Hypertens 17: 749-756.

12. Iglarz M, Touyz RM, Amiri F, Lavoie MF, Diep QN, Schiffrin EL (2003) Effect of peroxisome proliferatoractivated receptor-alpha and -gamma activators on vascular remodeling in endothelin-dependent hypertension. Arterioscler Thromb Vasc Biol 23: 45-51.

13. Ryan MJ, Didion SP, Mathur S, Faraci FM, Sigmund CD (2004) PPAR(gamma) agonist rosiglitazone improves vascular function and lowers blood pressure in hypertensive transgenic mice. Hypertension 43: 661666.

14. Tsai YS, Kim HJ, Takahashi N, Kim HS, Hagaman JR, Kim JK, Maeda N (2004) Hypertension and abnormal fat distribution but not insulin resistance in mice with P465L PPARgamma. J Clin Invest 114: 240-249.

15. Barroso I, Gurnell M, Crowley VE, Agostini M, Schwabe JW, Soos MA, Maslen GL, Williams TD, Lewis H, Schafer AJ, Chatterjee VK, O’Rahilly S (1999) Dominant negative mutations in human PPARgamma associated with severe insulin resistance, diabetes mellitus and hypertension. Nature 402: 880883.

16. Ikeda Y, Sugawara A, Taniyama Y, Uruno A, Igarashi 
K, Arima S, Ito S, Takeuchi K (2000) Suppression of rat thromboxane synthase gene transcription by peroxisome proliferator-activated receptor gamma in macrophages via an interaction with NRF2. J Biol Chem 275: 33142-33150.

17. Sugawara A, Uruno A, Kudo M, Ikeda Y, Sato K, Taniyama Y, Ito S, Takeuchi K (2002) Transcription suppression of thromboxane receptor gene by peroxisome proliferator-activated receptor-gamma via an interaction with $\mathrm{Sp} 1$ in vascular smooth muscle cells. $J$ Biol Chem 277: 9676-9683.

18. Majithiya JB, Paramar AN, Balaraman R (2005) Pioglitazone, a PPARgamma agonist, restores endothelial function in aorta of streptozotocin-induced diabetic rats. Cardiovasc Res 66: 150-161.

19. Miike T, Kunishiro K, Kanda M, Azukizawa S, Kurahashi K, Shirahase H (2008) Impairment of endothelium-dependent ACh-induced relaxation in aorta of diabetic $\mathrm{db} / \mathrm{db}$ mice--possible dysfunction of receptor and/or receptor-G protein coupling. Naunyn Schmiedebergs Arch Pharmacol 377: 401-410.

20. Martens FM, Visseren FL, de Koning EJ, Rabelink TJ (2005) Short-term pioglitazone treatment improves vascular function irrespective of metabolic changes in patients with type 2 diabetes. J Cardiovasc Pharmacol 46: 773-778.

21. Staniloae C, Mandadi V, Kurian D, Coppola J, Bernaski E, El-Khally Z, Morlote M, Pinassi E, Ambrose J (2007) Pioglitazone improves endothelial function in non-diabetic patients with coronary artery disease. Cardiology 108: 164-169.

22. Beyer AM, de Lange WJ, Halabi CM, Modrick ML, Keen HL, Faraci FM, Sigmund CD (2008) Endothelium-specific interference with peroxisome proliferator activated receptor gamma causes cerebral vascular dysfunction in response to a high-fat diet. Circ Res 103: 654-661.

23. Marx N, Walcher D (2007) Vascular effects of PPARgamma activators - from bench to bedside. Prog Lipid Res 46: 283-296.

24. Lim S, Jin CJ, Kim M, Chung SS, Park HS, Lee IK, Lee CT, Cho YM, Lee HK, Park KS (2006) PPARgamma gene transfer sustains apoptosis, inhibits vascular smooth muscle cell proliferation, and reduces neointima formation after balloon injury in rats. Arterioscler Thromb Vasc Biol 26: 808-813.

25. Joner M, Farb A, Cheng Q, Finn AV, Acampado E, Burke AP, Skorija K, Creighton W, Kolodgie FD, Gold HK, Virmani R (2007) Pioglitazone inhibits in-stent restenosis in atherosclerotic rabbits by targeting transforming growth factor-beta and MCP-1. Arterioscler Thromb Vasc Biol 27: 182-189.

26. Kudo M, Sugawara A, Saito A, Uruno A, Ito S (2006) Effects of pioglitazone, belaprost, and fluvastatin on gene expression in vascular endothelial cells revealed by DNA microarray analyses. J Hypertens 24 Suppl 6: 238-238.

27. Polikandriotis JA, Mazzella LJ, Rupnow HL, Hart CM (2005) Peroxisome proliferator-activated receptor gamma ligands stimulate endothelial nitric oxide production through distinct peroxisome proliferator-activated receptor gamma-dependent mechanisms. Arterioscler Thromb Vasc Biol 25: 1810-1816.

28. Werner C, Kamani CH, Gensch C, Böhm M, Laufs U (2007) The peroxisome proliferator-activated receptor-gamma agonist pioglitazone increases number and function of endothelial progenitor cells in patients with coronary artery disease and normal glucose tolerance. Diabetes 56: 2609-2615.

29. Sato K, Sugawara A, Kudo M, Uruno A, Ito S, Takeuchi K (2004) Expression of peroxisome proliferator-activated receptor isoform proteins in the rat kidney. Hypertens Res 27: 417-425.

30. Ahn KO, Lim SW, Yang HJ, Li C, Sugawara A, Ito S, Choi BS, Kim YS, Kim J, Yang CW (2007) Induction of PPAR gamma mRNA and protein expression by rosiglitazone in chronic cyclosporine nephropathy in the rat. Yonsei Med J 48: 308-316.

31. Arima S, Kohagura K, Takeuchi K, Taniyama Y, Sugawara A, Ikeda Y, Abe M, Omata K, Ito S (2002) Biphasic vasodilator action of troglitazone on the renal microcirculation. J Am Soc Nephrol 13: 342-349.

32. Guan Y, Hao C, Cha DR, Rao R, Lu W, Kohan DE, Magnuson MA, Redha R, Zhang Y, Breyer MD (2005) Thiazolidinediones expand body fluid volume through PPARgamma stimulation of ENaC-mediated renal salt absorption. Nat Med 11: 861-866.

33. Yang J, Zhang D, Li J, Zhang X, Fan F, Guan Y. (2009) Role of PPARgamma in renoprotection in Type 2 diabetes: molecular mechanisms and therapeutic potential. Clin Sci (Lond) 116: 17-26.

34. Chung BH, Lim SW, Ahn KO, Sugawara A, Ito S, Choi BS, Kim YS, Bang BK, Yang CW (2005) Protective effect of peroxisome proliferator activated receptor gamma agonists on diabetic and non-diabetic renal diseases. Nephrology (Carlton) 10 Suppl: S40-43.

35. Chung BH, Li C, Sun BK, Lim SW, Ahn KO, Yang JH, Choi YH, Yoon KH, Sugawara A, Ito S, Kim J, Yang CW. (2005) Rosiglitazone protects against cyclosporine-induced pancreatic and renal injury in rats. Am J Transplant 5: 1856-1867.

36. Blanquicett C, Roman J, Hart CM. (2008) Thiazolidinediones as anti-cancer agents. Cancer Ther 6: 25-34.

37. Yamauchi A, Takahashi I, Takasawa S, Nata K, Noguchi N, Ikeda T, Yoshikawa T, Shervani NJ, Suzuki I, Uruno A, Unno M, Okamoto H, Sugawara A. (2009) Thiazolidinediones inhibit REG Ialpha gene transcription in gastrointestinal cancer cells. Biochem Biophys Res Commun 379: 743-748. 